\title{
Legal justifications for gender parity on the bench of the International Court of Justice: An argument for evolutive interpretation of Article 9 of the ICJ Statute - CORRIGENDUM
}

\author{
Jessica Lynn Corsi
}

doi: 10.1017/S0922156521000443, published by Cambridge University Press 17 September 2021.

Keywords: evolutive interpretation; gender; ICJ; international organizations; judges; corrigendum

An omission was made from the Acknowledgements section in the original publication. The full listing is shown here;

Acknowledgements. The author would like to acknowledge and express gratitude for the research assistance of Ailsa McKeon, Donia Khaled El Maghrabi, Sudipta Purkayastha, and the editing assistance of Ceri Blower. The author would also like to acknowledge and express thanks to those that read, discussed, and/or offered helpful commentary or feedback on some form of this article, including J. Jarpa Dawuni, Michael Becker, Irina Buga, Luiza Leao Soares Periera, Alexandria Innes, Nienke Grossman, Laurel Fletcher, Massimo Lando, Jed Odermatt, María Noel Leoni, members of the ATLAS network for women in international law, members of GQUAL, the campaign for gender parity in international tribunals and monitoring bodies, and anonymous reviewers and editorial reviewers at the American Journal of International Law and the European Journal of International Law. The author would also like to thank the Violence and Society Centre at City, University London, the International Law and Affairs Group at City, University of London, the Cambridge Journal of International Law, and GQUAL for the opportunity to workshop and improve earlier versions of this article. Finally, the author would like to thank the anonymous peer reviewers and the editorial team of the LJIL for valuable feedback.

The author apologises for the error.

\section{Reference}

Corsi, J. (2021). Legal justifications for gender parity on the bench of the International Court of Justice: An argument for evolutive interpretation of Article 9 of the ICJ Statute. Leiden Journal of International Law 34, 977-1000. doi: 10.1017/ S0922156521000443

Cite this article: Corsi JL (2022). Legal justifications for gender parity on the bench of the International Court of Justice: An argument for evolutive interpretation of Article 9 of the ICJ Statute - CORRIGENDUM. Leiden Journal of International Law 35, 219. https://doi.org/10.1017/S0922156521000571

\footnotetext{
(c) The Author(s), 2021. Published by Cambridge University Press. This is an Open Access article, distributed under the terms of the Creative Commons Attribution licence (https://creativecommons.org/licenses/by/4.0/), which permits unrestricted re-use, distribution, and reproduction in any medium, provided the original work is properly cited.
} 